\title{
Attributes expected of a medical teacher by Malaysian medical students from a private medical school
}

\author{
Venkataramani, P.' , Krishnaswamy, . $^{2}$, Sugathan, $S .{ }^{3}$, Sadanandan, $T^{4}{ }^{4}$, Sidhu, \\ M.S. ${ }^{5}$, Gnanasekaran, A. $^{6}$
}

\begin{abstract}
Introduction: Medical education has moved from a teacher-centred to a learner-centred approach over the past few decades. The disparity between the expectations of students and the concepts of teachers may be a barrier for effective teaching.

Methods: This was a cross-sectional study conducted in University Kuala Lumpur Royal College of Medicine Perak. The attributes were rated on a 5-point Likert scale. The top 10 attributes were identified by calculating the mean score out of five overall and four subgroups. Attributes were grouped into four categories. The association between the scores and gender and phase of the study was analysed.

Results: A total of 459 students completed the questionnaire with 136 males, 323 females, and 194 preclinical, 186 early clinical and 79 late clinical students. The top 10 attributes overall were "enabled to understand basic principles", "made subject meaningful to clinical practice", "presented material logically and clearly", "enthusiastic", "spoke loudly and clearly", "treated students with respect", "showed concern for students", "showed expert knowledge", "was ethical", and "had no bias". Overall ranking of grouped attributes in descending order were "personal traits", "interaction with students", "teaching-related" and "teacher as a doctor". The attributes selected by students in this study were compared with that from other parts of the world.
\end{abstract}

Conclusions: Non-cognitive aspects such as "treated students with respect", "showed concern for students" and "enthusiasm for teaching" were rated above knowledge in this study.

Key Words: attributes, medical teacher, Malaysian medical students

\section{Introduction}

According to the General Medical Council, UK, "All doctors have a professional obligation to contribute to the education and training of other doctors, medical students and non-medical healthcare professionals on the team" (General Medical Council, 1999).

${ }^{1}$ Professor, Paediatrics, Faculty of Medicine,

UniKL Royal College of Medicine Perak, Ipoh, Malaysia.

${ }^{2}$ Scientific Officer, Forensic Sciences Department, Chennai, India.

${ }^{3}$ Senior Lecturer, Public Health, Faculty of Medicine, UniKL Royal College of Medicine Perak.

${ }^{4}$ Senior Lecturer, Paediatrics, Faculty of Medicine, UniKL Royal College of Medicine Perak, Malaysia.

${ }^{5}$ Associate Professor,

Preclinical Sciences,

UniversitiTunku Abdul Rahman, Malaysia.

${ }^{6}$ Lecturer, Faculty of Integrative Sciences and Technology, School of Biological Sciences,
QUEST International University Perak, Malaysia.

Corresponding Author:

Dr PadminiVenkataramani,

Professor, Paediatrics,

UniKL RCMP,

No.3, Jalan Greentown, 30450, Ipoh, Perak, Malaysia

E Mail:vpaddy1@hotmail.com

Learning in a clinical environment is different from that in classrooms and is quite a challenge for clinical teachers (Fluit et al., 2010). Medical education has moved from a teacher-centred to a learner-centred approach. Medical teachers are not data-banks of facts and experience imparting knowledge passively (Bihen, 1976). Medical students in different time-frames, countries and cultural backgrounds have different expectations of their teachers (Singh et al, 2013; Jahan et al., 2008; Sutkin et al., 2008). There may be barriers to effective teaching such as curricular, cultural, environmental, and financial (DaRosa et al., 2011). The disparity 
between the expectations of students and the concepts of faculty members regarding teaching could be one such barrier. Sir William Osler said, "It goes without saying that no man can teach successfully who is not at the same time a student" (Steinert, 2009).

A recent study from Melaka Manipal Medical College assessed 12 attributes, expected by their students. The top five were "ability to motivate and inspire", "ability to communicate well", "showing respect to students, peers and patients", "linking basic science to clinical practice", "providing hand-outs" (Singh et al., 2013).Another study from Pakistan (Jahan et al., 2008) described 13 attributes expected of a clinical teacher from a survey of teachers and students where students ranked "interest in teaching", "knowledge" and "clinical competency" and the teachers ranked "knowledge", "interest in teaching" and "clinical competency" as the top 3 attributes.

The review by Sutkin et al., (2008) gives a list of qualitative and quantitative studies undertaken to elucidate "the specific characteristics that make a good clinical teacher in medicine" from differing perspectives by various authors, mostly from Europe and North America, from 1909 to 2006.

This study was conducted in University Kuala Lumpur Royal College of Medicine Perak (UniKL RCMP), a private medical school where the majority of students are Malay with international faculty members having varied teaching backgrounds and experience. The students go through their first two years ("preclinical") in basic sciences and a special study module for research. Innovative methods of teaching such as system-based approach, small group tutorials and integrated learning activities are used. The next three years are spent in public heath, family medicine, clinical clerkships, electives and special study module for research. The third and fourth year students were grouped as "early clinical" and the final year students as "late clinical" students.

\section{Aim of the study}

The objective of this study was to identify the attributes expected of teachers by the students, awareness of which will hopefully modify the approach of the teachers to students and teaching. The attributes expected of a medical teacher by students were compared with those from other studies.

\section{Methodology}

This was a cross-sectional study, including all medical students from UniKL RCMP, and students of pharmacy, nursing, physiotherapy and radiography Programmes were excluded. The objectives of the study and method of answering the questionnaire were explained implied consent obtained. The response rate was 459 out of $562(81.67 \%)$. A questionnaire with demographic data (gender and year of study), and the 30 attributes was used. As the majority of students were Malay race was exclude from the demographic data.

The students were asked to rate the 30 attributes on a 5-point Likert scale from strongly agree (5 points) to strongly disagree (1 point). The mean score out of five was calculated for each attribute to identify the top 10 attributes.

Assuming that, at least $50 \%$ of students preferred each of the 30 selected attributes, with an allowable error of 5 , the minimum sample size was estimated to be 384 for $95 \%$ confidence interval. Though 562 students included to the study, incomplete questionnaires were excluded from analysis.

The attributes were selected based on literature review (Biehn et al., 1976; DaRosa et al., 201; Sutkin et al., 2008; Newble et al., 1994; Harden, 2000), interaction with mentees and consultations with experts in medical education, pretested among 284 medical students in another Malaysian university and modified. Data was entered in Excel data sheets. The mean score of the rating for each attribute was calculated. The attributes were grouped into four categories:

$$
\begin{aligned}
& \text { I. "Personal traits" } \\
& \text { II. "Teacher as a doctor" } \\
& \text { III. "Interaction with students" } \\
& \text { IV. "Teaching related" }
\end{aligned}
$$

The scores for individual and group attributes were tabulated overall and according to gender and phase of study of the students (Tables 1, 2 and 3). SPSS 15 and 17 were used for analysis. As normality tests showed markedly skewed data, nonparametric tests were done to look for associations between the attributes and gender and the phase of study.

\section{Results}

The questionnaire was distributed among the 562 medical students and 459 returned completed questionnaires. Out of 562136 (29.63\%) males and $323(70.37 \%)$ were females. 194 (42.27\%) preclinical, 186 $(40.52 \%)$ early clinical and $79(17.21 \%)$ were late clinical students. 
Table 1 shows the grouped attributes with mean, median scores and standard deviations according to gender. Table 2 shows the mean, median scores and standard deviations for the grouped attributes according to the phases of study. Overall, the mean score for attributes related to personal traits was the highest followed in descending order by "interaction with students", "teaching-related" and "teacher as a doctor". Females compared to males, showed a statistically significant higher preference for personal traits ( $p$ 0.01). There were no statistically significant differences in the scores in relation to the phases of study.

Table 1: Grouped attributes according to gender

\begin{tabular}{|c|c|c|c|c|c|c|}
\hline Grouped attributes & Gender & No. & $\begin{array}{l}\text { Mean for } \\
\text { groups }\end{array}$ & Median & $\begin{array}{c}\text { Std. } \\
\text { Deviation }\end{array}$ & $\begin{array}{c}\text { Mean for all } \\
\text { attributes/group }\end{array}$ \\
\hline \multirow[t]{2}{*}{ Personal traits - P: 6 traits } & $\mathrm{M}$ & 136 & 26.76 & 27 & 2.902 & 4.46 (No.1) \\
\hline & $\mathrm{F}$ & 323 & 27.58 & 28 & 2.354 & 4.60 (No.1) \\
\hline \multirow[t]{2}{*}{ Teaching-related - T: 10 traits } & $\mathrm{M}$ & 136 & 43.71 & 44 & 4.737 & 4.37 (No.2) \\
\hline & $\mathrm{F}$ & 323 & 43.75 & 44 & 4.064 & 4.37 (No.3) \\
\hline \multirow[t]{2}{*}{ Teacher as a doctor - TD: 5 traits } & $\mathrm{M}$ & 136 & 21.86 & 22 & 2.205 & 4.37 (No.2) \\
\hline & $\mathrm{F}$ & 323 & 21.72 & 22 & 2.469 & 4.34 (No.4) \\
\hline \multirow[t]{2}{*}{ Interaction with students - IS: 9 traits } & $\mathrm{M}$ & 136 & 38.99 & 40 & 4.181 & 4.33 (No.3) \\
\hline & $\mathrm{F}$ & 323 & 39.66 & 40 & 3.703 & 4.41 (No.2) \\
\hline
\end{tabular}

M: Male; F: Female All $p$ values $>0.05$ except for personal traits ( $p 0.01$ )

Table 2: Grouped Attributes overall and according to phase of study

\begin{tabular}{l|l|c|c|c|c}
\hline $\begin{array}{c}\text { Phase of } \\
\text { study }\end{array}$ & Statistics / Attribute groups $\rightarrow$ & $\begin{array}{c}\text { Personal } \\
\text { traits } \\
\text { P: } \mathbf{6} \text { traits }\end{array}$ & $\begin{array}{c}\text { Interaction } \\
\text { with students } \\
\text { IS: 9 traits }\end{array}$ & $\begin{array}{c}\text { Teaching- } \\
\text { related } \\
\text { T: 10 traits }\end{array}$ & $\begin{array}{c}\text { Teacher as a } \\
\text { doctor } \\
\text { TD: 5 traits }\end{array}$ \\
\hline Overall & Mean & 27.34 & 39.46 & 43.74 & 21.76 \\
& Median & 28 & 40 & 44 & 22 \\
& N & 459 & 459 & 459 & 459 \\
& Std. Deviation & 2.554 & 3.858 & 4.269 & 2.393 \\
& Mean for all attributes/group & 4.56 (No.1) & 4.38 (No.2) & 4.37 (No.3) & 4.35 (No.4) \\
\hline Preclinical & Mean & 27.03 & 39.17 & 43.70 & 21.94 \\
& Median & 28 & 40 & 45 & 22 \\
& N & 194 & 194 & 194 & 194 \\
& Std. Deviation & 2.701 & 4.217 & 4.610 & 2.331 \\
& Mean for all attributes/group & 4.51 (No.1) & 4.35 (No.4) & 4.37 (No.3) & 4.39 (No.2) \\
\hline Early clinical & Mean & 27.53 & 39.59 & 44.17 & 21.56 \\
& Median & 28 & 40 & 44 & 22 \\
& N & 186 & 186 & 186 & 186 \\
& Std. Deviation & 2.274 & 3.493 & 3.668 & 2.348 \\
& Mean for all attributes/group & $4.59($ No.1) & 4.40 (No.3) & 4.42 (No.2) & 4.31 (No.4) \\
\hline & Mean & 27.62 & 39.86 & 42.81 & 21.78 \\
& Median & 29 & 40 & 44 & 22 \\
& N & 79 & 79 & 79 & 79 \\
& Std. Deviation & 2.752 & 3.751 & 4.605 & 2.630 \\
& Mean for all attributes/group & $4.60($ No.1) & $4.43($ No.2) & 4.28 (No.4) & 4.36 (No.3) \\
\hline
\end{tabular}


Overall, the top 10 attributes were (Table 3):

1) "enabled me to understand the basic principles of the topic"

2) "made the subject meaningful to clinical practice"

3) "presented the material logically and clearly in an organised way"

4) "enthusiastic about teaching"

5) "spoke loudly and clearly"

6) "treated students as equals and with respect"

7) "showed concern for the students"

8) "showed an expert knowledge of the subject"

9) "was ethical"

10) "had no bias"

The first eight attributes were common to all the subgroups and each group ranked them differently. The mean score for "made the subject meaningful to clinical practice" was highest for early and late clinical students.

The following 10 attributes were also among the top 10 in the subgroups, as more than one attribute had the same mean score in some of the groups (Table 3).

- "passionate about own work"

- "accessible to students seeking advice"

- "recommended appropriate references"

- "punctual"

- "patient"

- "motivated me to read"

- "hardworking"

- "adopted an appropriate pace"

- "encouraged students to participate in class"

- "not intimidating"

The scores for the following attributes were significantly higher among female than male students $(p<0.05)$ :

- "had no bias"

- "accessible to students seeking advice"

- "treated students with respect"

- "motivated me to read"

- "gave hand-outs"

- "spoke loudly and clearly"

- "was firm with students"

Using online teaching methods had a very low ranking overall and in all the subgroups. The mean score for using online methods was significantly higher among male than female students and among preclinical students than among clinical students. $(p<0.05)$

There were statistically significant differences in the scores of the following attributes among the different phases of study $(p<0.05)$

- "Treated students with respect" was rated highest by late clinical students followed by early clinical and preclinical students.

- The rating for "only teach and not practice" was highest among preclinical students.

- "Punctuality", "presented the material logically and clearly", "made the subject meaningful to clinical practice", "provided constructive feedback" and "used white board", were rated highest by early clinical students followed by late clinical and preclinical students.

\section{Discussion}

The increasing emphasis on student autonomy over the years has resulted in changing roles for the teachers (Harden et al., 2000).A good teacher helps students to learn by taking on many roles such as an information provider, role model, facilitator, examiner, planner and resource developer (Harden et al., 2000). The perception of teachers regarding the desirable attributes of an effective teacher may be different from those of students.

This study was undertaken to identify the attributes desired by Malaysian medical students of their medical teachers. Awareness of the expectations of students may help teachers to modify their approach to students and make teaching more effective.

Ciraj et al., (2013)found the "ability to motivate" as the most desired attribute selected by students whereas in this study, only the late clinical students included this as one of the top ten attributes. Teachers in the study by Singh et al. (2013) selected "knowledge of the subject" as the top desired attribute. Jahan et al., (2008) reported that students selected "interested in teaching" while the teachers selected "knowledge", "clinical competency" and "interest in teaching" as the most desirable attributes. The students in the same study had selected "knowledge" and "clinical competency" as the second most important attributes. The students in this study rated "enthusiasm for teaching" as 
Table 3: Mean scores of attributes and ranking

\begin{tabular}{|c|c|c|c|c|c|c|c|}
\hline \multirow[t]{2}{*}{ OR } & \multirow{2}{*}{$\begin{array}{l}\text { Attributes } \\
\text { (Attribute groups in brackets) }\end{array}$} & \multicolumn{6}{|c|}{$\begin{array}{c}\text { Mean scores out of } 5 \text { - (Ranking in subgroups within } \\
\text { brackets) }\end{array}$} \\
\hline & & $\begin{array}{c}\text { Overal } \\
\text { I }\end{array}$ & Males & $\begin{array}{l}\text { Female } \\
s\end{array}$ & Pre Clin & $\begin{array}{l}\text { Early } \\
\text { Clin }\end{array}$ & $\begin{array}{l}\text { Late } \\
\text { Clin }\end{array}$ \\
\hline 1 & $\begin{array}{l}\text { Enabled me to understand the basic } \\
\text { principles of the topic }(T)\end{array}$ & 4.758 & $\begin{array}{c}4.691 \\
(1)\end{array}$ & $\begin{array}{c}4.786 \\
(1)\end{array}$ & $\begin{array}{l}4.690 \\
(1)\end{array}$ & $\begin{array}{c}4.833 \\
(2)\end{array}$ & $\begin{array}{l}4.747 \\
(2)\end{array}$ \\
\hline 2 & $\begin{array}{l}\text { Made the subject meaningful to clinical } \\
\text { practice }(T)\end{array}$ & 4.749 & $\begin{array}{c}4.676 \\
(2)\end{array}$ & $\begin{array}{l}4.780 \\
(2)\end{array}$ & $\begin{array}{c}4.639 \\
(4)\end{array}$ & $\begin{array}{c}4.860 \\
(1)\end{array}$ & $\begin{array}{l}4.759 \\
(1)\end{array}$ \\
\hline 3 & $\begin{array}{l}\text { Presented the material logically and clearly in } \\
\text { an organised way }(T)\end{array}$ & 4.728 & $\begin{array}{c}4.654 \\
(4)\end{array}$ & $\begin{array}{l}4.759 \\
(3)\end{array}$ & $\begin{array}{c}4.660 \\
(3)\end{array}$ & $\begin{array}{c}4.817 \\
(3)\end{array}$ & $\begin{array}{c}4.684 \\
(4)\end{array}$ \\
\hline 4 & Was enthusiastic about teaching $(\mathrm{T})$ & 4.723 & $\begin{array}{c}4.669 \\
(3)\end{array}$ & $\begin{array}{l}4.746 \\
(4)\end{array}$ & $\begin{array}{l}4.686 \\
(2)\end{array}$ & $\begin{array}{l}4.769 \\
(4)\end{array}$ & $\begin{array}{l}4.709 \\
(3)\end{array}$ \\
\hline 5 & Spoke loudly and clearly (P) & 4.682 & $\begin{array}{l}4.567 \\
(9)\end{array}$ & $\begin{array}{l}4.731 \\
(5)\end{array}$ & $\begin{array}{l}4.613 \\
(7)\end{array}$ & $\begin{array}{l}4.742 \\
(5)\end{array}$ & $\begin{array}{l}4.709 \\
(3)\end{array}$ \\
\hline 6 & $\begin{array}{l}\text { Treated students as equals and with respect } \\
\text { (IS) }\end{array}$ & 4.678 & $\begin{array}{l}4.581 \\
(7)\end{array}$ & $\begin{array}{l}4.718 \\
(6)\end{array}$ & $\begin{array}{c}4.608 \\
(8)\end{array}$ & $\begin{array}{l}4.720 \\
(6)\end{array}$ & $\begin{array}{l}4.747 \\
(2)\end{array}$ \\
\hline 7 & Showed concern for the students (IS) & 4.654 & $\begin{array}{l}4.647 \\
(5)\end{array}$ & $\begin{array}{l}4.656 \\
(8)\end{array}$ & $\begin{array}{l}4.624 \\
(5)\end{array}$ & $\begin{array}{c}4.699 \\
(7)\end{array}$ & $\begin{array}{l}4.620 \\
(5)\end{array}$ \\
\hline 8 & $\begin{array}{l}\text { Showed an expert knowledge of the subject } \\
\text { (TD) }\end{array}$ & 4.636 & $\begin{array}{l}4.635 \\
(6)\end{array}$ & $\begin{array}{c}4.641 \\
(10)\end{array}$ & $\begin{array}{l}4.588 \\
(9)\end{array}$ & $\begin{array}{c}4.683 \\
(8)\end{array}$ & $\begin{array}{l}4.620 \\
(5)\end{array}$ \\
\hline 9 & Was ethical (TD) & 4.630 & $\begin{array}{c}4.574 \\
(8)\end{array}$ & $\begin{array}{l}4.653 \\
(9)\end{array}$ & $\begin{array}{l}4.624 \\
(5)\end{array}$ & 4.612 & $\begin{array}{c}4.684 \\
(4)\end{array}$ \\
\hline 10 & Had no bias $(P)$ & 4.621 & 4.434 & $\begin{array}{l}4.700 \\
(7)\end{array}$ & 4.546 & $\begin{array}{c}4.672 \\
(9)\end{array}$ & $\begin{array}{c}4.684 \\
(4)\end{array}$ \\
\hline 11 & Was passionate about own work (TD) & 4.619 & $\begin{array}{c}4.654 \\
(4)\end{array}$ & 3.604 & $\begin{array}{l}4.619 \\
(6)\end{array}$ & 4.624 & $\begin{array}{l}4.608 \\
(6)\end{array}$ \\
\hline 12 & $\begin{array}{l}\text { Was accessible to students seeking } \\
\text { advice (IS) }\end{array}$ & 4.597 & 4.515 & 4.632 & 4.546 & 4.612 & $\begin{array}{c}4.684 \\
(4)\end{array}$ \\
\hline 13 & $\begin{array}{l}\text { Recommended appropriate references for } \\
\text { reading }(\mathrm{T})\end{array}$ & 4.597 & 4.507 & 4.634 & $\begin{array}{c}4.567 \\
(10)\end{array}$ & 4.634 & $\begin{array}{c}4.582 \\
(7)\end{array}$ \\
\hline 14 & Was punctual (P) & 4.576 & $\begin{array}{c}4.529 \\
(10)\end{array}$ & 4.596 & 4.492 & $\begin{array}{c}4.661 \\
(10)\end{array}$ & $\begin{array}{c}4.582 \\
(7)\end{array}$ \\
\hline 15 & Was patient $(\mathrm{P})$ & 4.569 & 4.485 & 4.604 & 4.505 & 4.634 & $\begin{array}{c}4.570 \\
(8)\end{array}$ \\
\hline 16 & Motivated me to read (IS) & 4.536 & 4.397 & 4.594 & 4.464 & 4.575 & $\begin{array}{l}4.620 \\
(5)\end{array}$ \\
\hline 17 & Was hard working $(\mathrm{P})$ & 4.510 & 4.441 & 4.539 & 4.536 & 4.457 & $\begin{array}{l}4.570 \\
(8)\end{array}$ \\
\hline 18 & Adopted an appropriate pace (T) & 4.451 & 4.312 & 4.467 & 4.428 & 4.457 & $\begin{array}{c}4.494 \\
(10)\end{array}$ \\
\hline 19 & Used audio visual aids effectively (T) & 4.434 & 4.456 & 4.425 & 4.454 & 4.489 & 4.256 \\
\hline 20 & Gave hand outs (notes) (IS) & 4.405 & 4.279 & 4.458 & 4.454 & 4.339 & 4.443 \\
\hline 21 & $\begin{array}{l}\text { Encouraged students to participate in } \\
\text { class (IS) }\end{array}$ & 4.401 & 4.301 & 4.443 & 4.366 & 4.366 & $\begin{array}{c}4.570 \\
(8)\end{array}$ \\
\hline 22 & Was not intimidating $(\mathrm{P})$ & 4.388 & 4.301 & 4.424 & 4.361 & 4.366 & $\begin{array}{l}4.506 \\
(9)\end{array}$ \\
\hline 23 & $\begin{array}{l}\text { Included material not readily accessible in } \\
\text { books }(T)\end{array}$ & 4.373 & 4.356 & 4.384 & 4.253 & 4.478 & 4.418 \\
\hline 24 & $\begin{array}{l}\text { Provided constructive criticism / feedback } \\
\text { (IS) }\end{array}$ & 4.331 & 4.279 & 4.353 & 4.175 & 4.468 & 4.392 \\
\hline 25 & $\begin{array}{l}\text { Teaching and also did his/her clinical / lab } \\
\text { duties (TD) }\end{array}$ & 4.205 & 4.221 & 4.198 & 4.268 & 4.134 & 4.215 \\
\hline 26 & Was informal with students (IS) & 4.041 & 4.059 & 4.034 & 4.057 & 4.043 & 4.000 \\
\hline 27 & Used the white board $(T)$ & 3.967 & 4.022 & 3.944 & 3.634 & 4.285 & 4.038 \\
\hline 28 & Was firm with students (IS) & 3.815 & 3.926 & 3.767 & 3.876 & 3.763 & 3.784 \\
\hline 29 & $\begin{array}{l}\text { Committed only to teaching, even if } \\
\text { he/she were a clinician / lab person (TD) }\end{array}$ & 3.671 & 3.787 & 3.622 & 3.835 & 3.505 & 3.658 \\
\hline 30 & Used Online learning methods eLMS (T) & 2.965 & 3.279 & 2.833 & 3.686 & 2.548 & 2.177 \\
\hline
\end{tabular}

Clin: clinical;eLMS: eLearning Management System; OR: Overall ranking;

Attributes in black font: Top 10 attributes; Attributes in black, bold font in italics: Other attributes among Top 10, in subgroups other than overall

Attribute groups in brackets: IS: Interaction with students; P: Personal traits; T: Teaching-related; TD: Teacher as a doctor; BOLD: Other attributes, after the top 10, in all groups; 
the fourth most important one and "knowledge" as the eighth desired attribute, overall. This highlights the fact that the expectations of students may be different from teachers and also may vary from country to country.

What makes a teacher effective, may vary with students from different countries and even on different occasions in the same students (Sutkin et al., 2008). Only the clinical students chose punctuality, as one of the top 10 attributes. The late clinical students in this study selected 20 characteristics as the top 10 attributes showing their high expectations from teachers. Studying in a medical school with international faculty, with varied accents probably led to the inclusion of "spoke loudly and clearly" as one of the top ten desirable attributes. Though teachers are expected to be role models at the work-place, the students in this study did not place importance on whether or not the teachers had clinical responsibilities in the hospital or worked in the laboratory. However, there was statistically significant difference between the different phases of students for "teachers committed only to teaching", the preclinical students rating it higher than the clinical students.

Although feedback is mentioned in the post1970 articles (Sutkin et al., 2008), students in this study ranked it 24 . In this digital era, it is surprising that the students rated competence in e-learning as the lowest desired attribute. It is possible that they faced challenges with the English language and lack of seamless internet connectivity. Even the rating for the "effective use of audio-visual aids" was ranked 19.

Non-cognitive attributes such as "treated students with respect", "showed concern for students", and "enthusiasm for teaching" were rated above knowledge in this study. Sutkin et al., (2008) emphasise that the acquisition of non-cognitive, relationship-based, personal attributes, which are more difficult to develop and teach, is most important for effective teaching.

Among the attribute groupings, "personal traits" were rated highest by all the groups, followed in descending order by "interaction with students", "teaching-related" and "teacher as a doctor". Preference for personal traits was significantly higher among female compared to male students $(p<0.01)$.

\section{Conclusion}

The strength of this study is the large number of students who participated. The limitations are inadequate representation of all races and the use of 30 attributes which might have confused the students. A qualitative study which is planned using focus groups in future may help to highlight the importance of the non-cognitive traits desired by students in their teachers and also help to understand the reasons for the poor rating for e-learning.

Being a teacher which is perceived as a favourable quality or skill, requires time and effort (Burke, 2014). Faculty development Programme should include non-cognitive attributes of effective teachers, though it may be a difficult task. These Programme should also target curriculum planners, administrators who recruit teachers and healthcare professionals involved in teaching (Steinert, 2009). They should focus on the expectations of the students who are the stakeholders in any teaching Programme.

\section{Acknowledgements}

The same study was accepted for an interactive poster presentation for NCHPE 2014 at Sevagram, India.

\section{Sincere acknowledgements to}

- The encouragement of the Dean, Prof. Dr Osman Ali, MdmResni Mona Abdullah, Associate Prof. Dr Noorzaid Muhamad and Assoc. Prof. Dr V.Gopalakrishnan during and after the Journal Writing Workshop, UniKL RCMP, Ipoh, Malaysia,

- Dr. Muhammad Imran Ahmad, UniKL RCMP for his help with MS Office and Prof. Dr. V.Sitaram, CMC, Vellore for the editorial help

\section{Conflict of interest: None}

Ethical clearance: from Institutional Review Board

\section{References}

Biehn, J.T. (1976) Characteristics of an effective medical teacher, Canadian Family Physician, 22, p. 135.

Burke, A. (2014) Competency 8. Develop the necessary skills to be an effective teacher, Academic Pediatrics, 14, 2, pp. S50-S52.

Ciraj, A.M., Abraham, R.R., Pallath, V., Ramnarayan, K., Kamath, A. \& Kamath, R. (2013) Exploring attributes of effective teachers - student perspectives from an Indian medical school, South-East Asian Journal of Medical Education, 7, 1, pp. 8-13. 
DaRosa, D.A., Skeff, K., Friedland, J.A., Coburn, M., Cox, S., Pollart, S., O'Connell, M. \& Smith, S. (2011) Barriers to effective teaching, Academic Medicine, 86, 4, pp. 453-459.
Fluit, C.R., Bolhuis, S., Grol R., Laan R. \& Wensing, M. (2010) Assessing the quality of clinical teachers Journal of General Internal Medicine, 25, 12, pp. 1337-1345. 